\title{
LEGAL ASPECTS OF CENTRAL BANKING IN SLOVENIA AND CROATIA FROM THEIR BEGINNINGS UP TO MEMBERSHIP OF THE EURO AREA
}

\author{
Meta Ahtik*, Zrinka Erent Sunko**, and Ozren Pilipović ${ }^{* * *}$
}

\begin{abstract}
Summary: The right to regulate the monetary system represents one of the immanent features of state sovereignty. A central bank is an institution that is usually given the authority to conduct a country's monetary policy. Slovenia entered the European Union in 2004, the Bank of Slovenia became part of the Eurosystem, and its governor a member of the Governing Council of the ECB that decides on the monetary policy of the euro area. At the moment, Croatia is about to enter the European Union. Both countries were parts of the former socialist Yugoslavia (SFRY) and so have not come a long way on their own. However, their experiences with an independent central bank cannot be neglected. Therefore, it is useful to explore how central banking was organised in the past: before SFRY, in SFRY, and after gaining independence.
\end{abstract}

\section{Introduction}

Under international law, monetary sovereignty is considered to be one of the attributes of a modern state. The right to regulate the monetary system resides within the state ${ }^{1}$ and although this right can be transferred to an international organisation or to another state, it cannot be handed over perpetually, as it represents one of the immanent features of state sovereignty. In fact, an act of a state whereby monetary sovereignty is transferred can only be of a temporary character, since otherwise the statehood of such a country would be disputed. ${ }^{2}$

A central bank is an institution that is usually given the authority to conduct a country's monetary policy by means of a country's supreme legal act, ie its constitution. Slovenia has experienced many monetary

\footnotetext{
* Assistant Professor, Faculty of Law, University of Ljubljana; Postdoctoral Researcher at the European Central Bank.

** Assistant Professor, Faculty of Law, University of Zagreb.

*** Assistant Professor, Faculty of Law, University of Zagreb

1 Charles Proctor, Mann on the Legal Aspect of Money (OUP 2005).

2 Meta Ahtik, 'Monetarna suverenost in Banka Slovenije po uvedbi evra' (2005) 65 Zbornik znanstvenih razprav 29.
} 
changes in the recent past that were connected to transformations in the central banking structure and central bank governance. These issues will be thoroughly addressed in this paper. All these important changes were accompanied by modifications in the central banking legal framework. Since the present functioning of social institutions quantitatively and/or qualitatively depends on its past (path dependency), it might be useful to explore how central banking was organised in former times. In fact, the functioning of institutions in the multi-country environment of Yugoslavia can provide a useful (negative) example for the European Union.

After being part of a socialist country that went through several development stages, which had an impact also on central banking legislation, Slovenia and Croatia gained their independence in June 1991, when they also established their new central banks (in the case of Croatia, this took place in October 1991). In Slovenia, the new currency, the tolar, was declared legal tender in October 1991 after a moratorium on independence procedures had been lifted. Croatia introduced the Croatian dinar in December 1991 followed by the Croatian kuna in May 1994. Slovenia entered the European Union in 2004 and was the first of all the new Members States to introduce the euro in 2007. The European Central Bank (ECB) governing structure is designed for decision-making in a large, multi-country environment based on the principle of equality between Member States, although changes are about to be put into effect that could bring inequality among Member States and make decision-making non-transparent. At the moment, Croatia is in the process of joining the European Union, whereas membership in the euro zone is not considered a likely possibility in the near future.

\section{Central banking in Slovenia and Croatia until 1945}

The first signs of central banking can be found on the territory of the Austrian Empire at the beginning of the $19^{\text {th }}$ century, even though banknotes had been issued at least fifty years before that. The Wiener Stadtbank, which was founded in $1705,{ }^{3}$ started printing paper money in 1762. It was an independent bank and thus enjoyed the trust and respect of the business community. At the end of the $18^{\text {th }}$ century, during the Napoleonic wars, the Austrian state started printing money and issuing banknotes that became the legal currency of the Austrian Empire as of 1799. The state's involvement in money printing led to inflation. At the end of the Napoleonic wars, the Austrian Empire founded its first central bank, the privilegirte österreichische National-Bank and

\footnotetext{
3 In 1705, Bank-institut, and since 1706 Wiener Stadtbank.
} 
the public felt confident again about the money supply in the Empire. The Austrian National Bank issued shares. Fifty (later, one hundred) of the biggest shareholders were represented on the Governing Board (Bankausschuss). The representatives of the shareholders together with the eight temporary directors and the state commissioner appointed the 'executive governing board' (der engere Ausschuss) made up of twelve members, whose appointment had to be confirmed by the emperor (article 30 of the first privilege). Its main function was to shape bank rules and bank statues by cooperating with state commissioners, and all of this had to be confirmed by the emperor. As long as the number of shares did not reach 1,000, the bank was governed by eight temporary directors, among whom one was appointed governor by the emperor himself.

Article 21 of the first privilege stipulated that the privilegirte österreichische National-Bank was also represented by the Directory, and not only by the Governing Board. The Directory managed the bank's assets. In accordance with article 25 of the privilege, the bank was held accountable to the state for conducting its business in a fair, prudent and legal way. The Directory appointed the governor, his deputy and seven directors. When half of the bank's founding capital was reached, the number of directors was increased to twelve (article 28). The second privilege in 1841 kept the governing structure of the Austrian National Bank intact, which was changed however by the third privilege in 1862 .

In 1817, the Austrian National Bank was granted the exclusive right to issue banknotes, and in July 1817 it was granted the right to make discount operations. Money transactions played an important role in the creation of a single market on the territory of the Austrian Empire. The Austrian National Bank established its branches in almost every industrial centre of the empire and provided loans for emerging industry.

The Governing Board set the interest rates together with the Directory (article 43).The Board also monitored the balance sheet of the bank on a half-yearly basis and provided reports to shareholders (article 44).

In 1841 the state increased its hold on the Austrian National Bank. In 1862, with the Bank Act ${ }^{4}$ the Austrian National Bank became independent from the government and an upper limit for the issue of banknotes was set. In practice, this newly proclaimed independence was not strictly respected, as during the 1866 Austro-Prussian war the state financed itself by printing money. In 1862, the functions of the Governing Board were performed by the bank Shareholders Assembly. Its members were all shareholders who, pursuant to article 33 of the Bank Act had at least 12 stocks on their name. The 1862 Central Bank Act stated that di-

4 Imperial Law Gazette 2 (1863). 
rectors were to be appointed by the Shareholders Assembly but were still to be confirmed by the emperor. The Shareholders Assembly was to meet once a year for its regular meeting, at which at least fifty shareholders had to be present. In extraordinary circumstances, a General Assembly was called by the Directory or by at least forty shareholders (article 35 of the 1862 Central Bank Act).

After the introduction of Dualism in 1866, the National Bank of Austria continued to operate as the central bank of Austro-Hungary. In monetary affairs, Dualism was present only from 1878, when a new central bank was created. Austria and Hungary had equal shares in this institution, although, according to some sources, 'there was an Austrian majority in the council, and the ratio of notes, government profit shares etc, was generally 70 Austria to 30 Hungary' ${ }^{5}$ It had two directories, in Vienna and in Budapest. The common monetary policy was shaped by the General Assembly (Generalversammlung) and the General Council (Generalrat) of the central bank. At first, regular meetings of the General Assembly were held in Vienna. They were chaired by the governor or by one of the deputy governors. The General Assembly was deemed to be valid if at least 100 shareholders were present. After the amendments to the third privilege of the Austro-Hungarian bank in 1899 (article 23), General Assembly meetings were held either in Vienna or in Budapest depending on the nationality of the majority of shareholders. In accordance with article 26, the General Council was made up of the governor, two deputy governors and twelve members of the Council. The General Council replaced the Directory. By means of the 1899 Central Bank Act, the number of deputy governor seats was increased to four.

The new 1899 Austro-Hungarian National Bank Act reduced the autonomy of the central bank and increased the governments' influence on the printing of money. The Act also served as a basis for the exchange rate policy, ${ }^{6}$ which maintained the stability of the krone. In that period, the gold krone replaced the silver forint, although banknotes had already been widely circulating. From 1890 to 1910, the Austro-Hungarian National Bank was one of the European banks most under the power of the government. ${ }^{7}$

\footnotetext{
5 Charles Goodhart, quoting Zuckerkandl, 'The Austro-Hungarian Book, Banking in Italy, Russia, Austro-Hungary and Japan' Statistical Tables, National Monetary Commission (1911) XVIII 116 in Charles Goodhart, The Evolution of Central Banks (MIT Press 1991).

6 See Thomas Scheiber, 'The Experience of Exchange Rate Regimes in Southeastern Europe in a Historical and Comparative Perspective' (2nd Conference of the South-Eastern European Monetary History Network, no 13, 2007) <http//www.oenb.at/de/img/austrohungarian_empire_tcm14-80907.pdf> accessed 5 July 2011.
}

7 Goodhart (n 5). 
The Austro Hungarian bank had branches in Croatia and Slavonia ${ }^{8}$, but monetary transactions were relatively meagre. ${ }^{9}$

With the collapse of the Monarchy, the monetary area also broke up and the new states on the territory of the former Austro-Hungarian Empire were forced to implement monetary segregation and create their own monetary areas, since Austria took seigniorage from the countries that continued to use the krone. This led to a monetary 'divorce' between the successor states, with the krone being exchanged for the respective domestic currency, and the liquidation of the Austro-Hungarian bank. ${ }^{10}$ The liquidation of the bank was regulated by the terms of the Saint-Germaine Treaty. The last Common Assembly of the bank was held in July, but the General Council continued to operate until 1922.

With the 1918 proclamation of the Kingdom of Serbs, Croats and Slovenes, Croatia and Slovenia became members of the monetary area of the new kingdom. The National Bank of the new state was founded in 1920 simply by proclaiming the National Bank of Serbia the National Bank of the new state. The bank took over all the branches of the Austro-Hungarian National Bank in the Kingdom and opened 24 new branches.

After the 1931 financial crash, banks were divided between those privately owned in the west of the country (Croatia and Slovenia) and those state-owned and sponsored by the National Central Bank in the east (Serbia).The political disintegration of Yugoslavia in 1941 was followed by a monetary one.

\section{Central banking in the Socialist Federative Republic of Yugoslavia (SFRY)}

After the 1945 liberation, the National Bank of the Democratic Federal Yugoslavia started to operate and it was in turn proclaimed successor to the National Bank of the Kingdom of Yugoslavia. Private banks of any form were either nationalised or abolished.

Central banking in Yugoslavia functioned as a fully mono-banking system from 1947 to 1954 . All banking functions were carried out by a

\footnotetext{
8 M Kolar-Dimtrijević, 'Državne i zemaljske banke u Hrvatskoj do 1945' (2000) 53 Historijski zbornik 125.

9 During the troubles with the Hungarians in 1848, a type of state bank under the name 'Deržavna kasa' was founded. In 1846 in Zagreb, the financial institution 'Prva hrvatska štedionica' was established. From 1868 onwards, Austro-Hungarian settlement allowed for the foundation of banks on the territory of the Monarchy. New financial institutions for capital investment emerged in Croatia during the late 1860s.

10 Z Jelinčič, Dinarsko kronska serija (Samozaložba 1997).
} 
single bank that was also the central bank with an emission function. After 1954, the establishment of the first communal banks and saving banks started and performed functions in the granting of short-term loans. In the following years, some specialised banks like the Yugoslav Investment Bank, the Yugoslav Foreign Trade Bank and the Yugoslav Agricultural Bank were founded. In 1962, the National Bank started its activity, but only in the function of an emission bank. Republic central banks were established in 1973, following the decentralisation process carried out also in other fields of socio-political life. ${ }^{11}$ The separate functioning of the central bank and of commercial banks (dual banking) represents one of the crucial differences between the Yugoslav banking system and other socialist banking systems. In comparison, the functioning of commercial banks in the new situation of transition to a market economy was much easier for Slovenia and Croatia, as banks were already operating there (although in very different circumstances). In fact, other former socialist countries had to organise their commercial banking first. It must be emphasised that the functioning of the central bank was right to the end much closer to the performance of other socialist central banks, although it de facto used market-based instruments, but they were exercised in a way typical of central planning. The central bank was used to support political objectives (budget deficit financing).

Following decentralisation efforts, competence for central banking legislation was divided between the federal legislative body and the legislative bodies of the six republics (all of them independent states now) and the two autonomous provinces (Kosovo and Vojvodina). Article 260 of the 1974 Constitution of SFRY ${ }^{12}$ declared the National Bank of Yugoslavia, the national banks of the republics and of autonomous provinces (NBRAP) to be institutions of a uniform monetary system. This type of organisation is typical of a federal state. ${ }^{13}$

The independence of the central bank was not ensured, since the National Bank of Yugoslavia adjusted the amount of money in circulation according to the common emission policy as determined by the National Assembly (article 268 of the Constitution). A higher level of independence, although not sufficiently high, was introduced in 1989. ${ }^{14}$

\footnotetext{
11 Dušan Mramor, 'Prikaz institucionalne ureditve bančno-kreditnega in nekaterih drugih delov ekonomskega sistema Jugoslavije 1945-1983' (1985) 1-2, 3 ZBS, Bančni vestnik 14,51 .

12 Official Gazette SFRY 9/1974.

13 Similar regulations can be found in Germany and in the United States.

14 Darko Bohnec, 'Kaj prinaša novi zakon o Banki Jugoslavije?' (1989) 6 ZBS Bančni vestnik 197.
} 
Federal-level decision-making was divided between two bodies: the Governing Board and the governor of the National Bank of Yugoslavia (article 77 of the Act on the National Bank of Yugoslavia and the Uniform Monetary Operations of the NBRAP. ${ }^{15}$ The Governing Board was composed of the governor of the National Bank of Yugoslavia ${ }^{16}$ and the governors of the NBRAP (article 78 of the Act on the National Bank of Yugoslavia and Uniform Monetary Operations of the NBRAP).

The NBRAP were responsible for taking other measures necessary for the implementation of the credit policy of the republics or autonomous provinces. The decision on the allocation of other tasks between the National Bank of Yugoslavia and the NBRAP was taken by the Governing Board. Governors of the NBRAP were accountable to the National Assembly of Yugoslavia and to the National Assembly of their republic.

Governors of the NBRAP were nominated according to national laws. The National Bank of Slovenia had a governing structure that somewhat resembled the structure of a federal central bank. Its decision-making system was divided into two functions: the executive (governor with vicegovernors) and the advisory (Governing Board) functions. Members of the Governing Board were the governor and fourteen delegates nominated by the National Assembly (article 54, National Bank of Slovenia Act). Governing Board members represented particular public, economic and scientific interests. Ten of the members of the Governing Board were nominated by the House of Associated Labour (one of three houses of the National Assembly) on a proposal of the Chamber of Commerce and Industry, two represented socio-political communities, and two were experts in the monetary field.

The composition, tenure and tasks of both Governing Boards, the federal and republic boards, confirm that the central bank pursued mostly political and particular economic interests.

\section{Central banking in Slovenia after independence}

The 1990s brought about major changes: not only did Slovenia gain its independence for the first time in its history, but also the democratic changes that started in the 1980s were accomplished.

Slovenia's gaining of independence was marked by the principle of legal continuity that also manifested itself in the central banking legislation. The newly established Bank of Slovenia was declared to be a legal successor of an old National Bank of Slovenia (article 94 of the Act on the

15 Official Gazette SFRY 34/1989.

16 He was appointed by the National Assembly. 
Bank of Slovenia). ${ }^{17}$ Besides that, the governor and vice-governors of the National Bank of Slovenia maintained their functions until their terms of office expired (article 95 of the Act on the Bank of Slovenia). Personal and institutional continuity of central banking was ensured.

The establishment of the new central bank was also used to implement some basic modern central banking standards. The independence of the central bank had already been established with the Act on the Bank of Slovenia ${ }^{18}$ and was confirmed by a Constitutional norm in December $1991 .{ }^{19}$ The guarantee of independence signified important progress compared to previous legislation, although some deficiencies still existed. Budget financing within one fiscal year was still possible (article 61 of the Act on the Bank of Slovenia) although it was never used. ${ }^{20}$ Besides that, the governor had the possibility of notifying the National Assembly, which was supposed to take a final decision if the Governing Board could not reach an agreement, if he was of the opinion that he could not carry out his tasks and responsibilities (article 21 of the Act on the Bank of Slovenia).

Another important adjustment was the accommodation of the structure of the Governing Board. It used to be composed of delegates nominated on political grounds. The newly passed Act on the Bank of Slovenia temporarily transferred the functions of the Governing Board - obviously a relic of the old self-management system - to the governor until the new Governing Board was nominated, which happened within one month. The Act on the Bank of Slovenia retained the governing structure of the bank known from the times of the National Bank. The Governor and the Governing Board of the central bank continued to be the two main decision-making bodies (article 11 of the Act on the Bank of Slovenia). The latter was composed of eleven members with a six-year term of office: the governor, deputy governor, three vice-governors and six independent experts (article 12 of the Act on the Bank of Slovenia). It is clear that political and particular economic interests were no longer represented in the Governing Board. All members were appointed by the National Assembly upon the proposal of the Presidency (or, after the passing of the new Constitution, the President) of the Republic of Slovenia. In addition, the prolonged term of office of the members of the Governing Board confirms that the goal of independence was pursued. The governor and

\footnotetext{
17 Official Gazette of the Republic of Slovenia, 1/91-I.

18 Official Gazette of the Republic of Slovenia 33/91-I.

19 Article 152 of the Constitution: 'Slovenia has a central bank. In its functioning the bank is independent and directly accountable to the National Assembly. The central bank is established by law'.

20 Milan Cvikl and Metka Kuhar, 'Kako je nastajala slovenska centralnobančna zakonodaja' (2001) 5 ZBS Bančni vestnik 33.
} 
all the members of the Governing Board were nominated by the National Assembly. Performing the function of a member of the Governing Board was incompatible with working for institutions supervised by the Bank of Slovenia or with the position of an elected or appointed public official.

The new legislation established modern central banking, ensuring its independence, while removing the relics of the socialist and self-management system on the one hand, and guaranteeing continuity of central banking on the territory of Slovenia on the other.

\section{Central banking in Croatia after independence}

As in Slovenia, the 1990s also brought changes to the Croatian National Bank. Even before Croatia gained its independence from Yugoslavia in 1991, pursuant to article 53 of the 1990 Constitution of Croatia, ${ }^{21}$ the Croatian Central Bank was proclaimed the Croatian National Bank. The position of the National Bank of Croatia was to be regulated by a special law. The provisions of article 53 of the 1990 Croatian Constitution stipulated that the Croatian National Bank should be independent and accountable only to the Croatian Parliament with price stability as its main objective. On 8 October 1991, the Croatian government published the Act on the National Bank, ${ }^{22}$ which set forth that there should be a governor and three deputy governors, as well as a council of the Croatian National Bank comprised of six members (the government proclaimed this with a regulation instead of a law since there was a war in Croatia at that time). In 1992, the Parliament of Croatia finally passed the law regulating the Croatian National Bank. The money was also changed, first with the introduction of the Croatian dinar on 23 December 1991 and then with the introduction of the kuna on 30 May 1994.

Croatia opted for personal continuity in its National Bank in more limited ways, as the existing governor was allowed to keep his office until 1992. The National Bank Act ${ }^{23}$ was a curious mixture of newly introduced modern central banking standards and the old view according to which a central bank was there to help the government's economic policy. Article 2 of this Act proclaimed that the Croatian National Bank had to help the economic policy of the government, except in cases where this would threaten overall price stability and liquidity. ${ }^{24}$ Although the Croatian National Bank was allowed to pass its own Articles of Association, this still had to be confirmed by the Croatian parliament. The

21 Official Gazette of the Republic Croatia 056/1990.

22 Official Gazette of the Republic Croatia 071/1991.

23 Official Gazette of the Republic Croatia 074/1992.

24 ibid. 
organs of the bank are the governor and the Governing Council. The Croatian parliament was to appoint the members of the council among prominent independent economic experts. In 2001, a new Croatian National Bank Act was passed, which significantly strengthened the independent position of the bank. In 2006, this Act was amended in order to make institutional changes necessary for any future membership of Croatia in the euro area. In 2008, a new Act concerning the central bank was passed ${ }^{25}$. As in previous acts, the governing bodies of the Bank were the governor and the Governing Council. The governor is appointed by the Croatian parliament for a term of six years (the law does not clearly state this but since the term for the member of the Governing Council is six years it can be presumed that this holds true for the governor as well). The parliament appoints the governor following a recommendation by the parliament's Finances Committee. The members of the Governing Council are elected by parliament among independent economic experts for a term of six years, though the chairmen of the parliament Finance Committee and the Finance Minister are ex officio members of the Council. This was done in order to better coordinate cooperation between the fiscal and monetary authorities and also to allow the governing party to have a say in discussions about monetary policy. The prolonged term of office of both Governing Board members and of the governor confirms that the goal of independence was followed in Croatia as well. ${ }^{26}$ The bank managed to retain its monetary autonomy in spite of fierce criticism by the ruling political coalitions in the early part of the 2000 s.

The new legislation established modern central banking in Croatia and ensured its independence. Furthermore, it removed the relics of the socialist and self-management system, while at the same time guaranteeing continuity of central banking on the territory of Croatia, although in more narrow terms than in the case of Slovenia.

\section{Central banking in Slovenia after membership in the euro area}

When Slovenia entered the European Union it was already known that the rights representing monetary sovereignty would have to be transferred to the European Union, because all members (except for the United Kingdom and Denmark who had been provided with an opt-out clause) are obliged to introduce the euro at a certain point of time. The transfer of monetary sovereignty in Slovenia had to be done by means of the highest state legal document - the Constitution. The handover of monetary sovereignty is not explicit, since the general nature of con-

25 Official Gazette of the Republic Croatia 75/2008.

26 The term of office of a governor and of council members is fixed to six years and is renewable. 
stitutional norms does not allow for this. Article 3a of the Constitution of Slovenia states that Slovenia may transfer the exercise of part of its sovereign rights to international organisations which are based on the respect of human rights and fundamental freedoms, democracy and the principles of the rule of law and may enter into a defensive alliance with states based on the respect of these values. ${ }^{27}$

Paragraph three of the above-mentioned Article 3a stipulates that legal acts and decisions adopted by international organisations, to which Slovenia has transferred the exercise of part of its sovereign rights, shall be applied in Slovenia in accordance with the legal regulation of these organisations. Limitations on withdrawal from these organisations may be a part of their legislation, as is the case with the European Union which does not explicitly allow for withdrawal, although this is permitted in the Lisbon Treaty, which is currently in the process of ratification. ${ }^{28}$

Since the transfer of the exercise of sovereignty was confirmed by the people's will in a referendum, ${ }^{29}$ it may be presumed that if the nation changed its opinion, the transfer could be withdrawn, especially taking into consideration the United Nations Charter provision that provides for the right to self-determination. ${ }^{30}$ Withdrawal from the euro area has not been legally regulated at all, but it would represent a breach of European Treaties. The consequences of such an act would depend on the political situation at the moment of withdrawal. The final decision on membership in, and withdrawal from, international organisations remains a political issue. ${ }^{31}$

Before the euro was introduced in Slovenia, the question was raised whether it was necessary to call another referendum on the introduction of the new currency. It was agreed that the people had already decided on that issue when they voted for membership in the European Union, which was immanently connected with membership of the euro area.

${ }^{27}$ From the way the article is expressed, it is clear that it is targeted at membership of the European Union and NATO.

28 Article 58 of the Treaty of Lisbon states that any Member State may decide to withdraw from the European Union in accordance with its own constitutional requirements.

29 Article 3a of the Slovenian Constitution allows for a referendum, but it is not obligatory: The Treaty shall be ratified by the National Assembly by a two-thirds majority vote of all deputies. A referendum may be called before ratifying a Treaty. A proposal shall pass at the referendum if a majority of voters who have cast valid votes vote in favour of such. The National Assembly is bound by the result of such referendum'.

30 Art 1 para 2 of the Charter of the United Nations: 'To develop friendly relations among nations based on respect for the principle of equal rights and self-determination of peoples, and to take other appropriate measures to strengthen universal peace'.

31 For more about the legal consequences of a withdrawal, see Proctor (n 1); and Meta Ahtik, 'Nekateri pravni vidiki izstopa iz evroobmočja' (2006) 3 Bančni vestnik 2. 
The new Bank of Slovenia Act was passed in 2002. It incorporates most of the necessary measures for membership of the euro area. The new Act reduces the number of members of the Governing Board of the Bank of Slovenia to five officials: the governor and four vice-governors. ${ }^{32}$ Independent experts are no longer members of the Governing Board. One of the vice-governors is given the authority by the governor to act as deputy governor. The number of Governing Board members is being reduced gradually; when their terms of office expire they are no longer replaced with new officials. Currently, the number of Governing Board members is seven: the governor, the deputy governor, two vice-governors and three members of the Governing Board. The reduction in the number of members is reasonable, since monetary policy decision-making has been transferred to the ECB level, where governors of national central banks participate in the Governing Council of the ECB.

The ECB has two decision-making bodies. The Executive Board is composed of persons of recognised standing and professional experience in monetary or banking matters who are selected by common accord of the governments of the Member States at the level of the Heads of State or Government, on a recommendation from the Governing Board after it has consulted the European Parliament and the Governing Council. ${ }^{33}$

The other body is the Governing Council composed of Executive Board members and the governors of the national central banks. Article 14 of the Statute of the ESCB and the ECB provides for some requirements regarding the governance structure of national central banks, while other provisions remain within the authority of a single Member State as long as they are compatible with the Treaty and the Statute. ${ }^{34}$ In accordance with the current regulation, the governor of every central bank of a euro area Member State is a member of the Governing Council of the ECB. Since all members of the Governing Board are appointed in their personal capacity, governors do not act as representatives of their countries. ${ }^{35}$ The principle of one country - one vote is used. ${ }^{36}$ Exceptions to this rule relate to decisions on the capital of the ECB, the key for capital subscription, transfer of foreign reserve assets, the allocation of monetary income and the allocation of net profits and losses. Votes in these

\footnotetext{
32 The Bank of Slovenia Act 2002.

33 Protocol on the Statute of the European System of Central Banks and of the European Central Bank [1992] OJ C191, 68.

34 The term of office of a governor of a national central bank shall be no less than five years, a governor may be relieved of office only if he no longer fulfils the conditions required for the performance of his duties or if he has been guilty of serious misconduct.

35 JV Louis, 'L'Union économique et monetaire' in Commentaire Megret, Le droit de la CEE (2nd edn, vol 6, Editions de l'Université de Bruxelles 1995) 66.

36 Protocol (n 33).
} 
areas of decision-making are weighted according to the national central banks' shares in the subscribed capital of the ECB. ${ }^{37}$

Responsibilities are divided between both bodies: policy is determined by the Governing Council, while the executive level decision-making is done by the Executive Board. The Governing Council formulates the monetary policy and takes decisions relating to intermediate monetary objectives, key interest rates and the supply of reserves in the ESCB and establishes the necessary guidelines for their implementation. The Executive Board implements monetary policy in accordance with the guidelines and decisions laid down by the Governing Council. The Governing Council may delegate some powers to the Executive Board. ${ }^{38}$

The principle according to which decision-making should be targeted at the average economic situation of the euro area, and not to a certain Member State or Member States, ${ }^{39}$ is put into force by the membership of Executive Board members in the Governing Council. However, their weighting diminishes as new members enter the euro area, and this was one of the reasons that led to a change of the regulation as will be described below.

\section{Allocation of voting rights under the new article 10(2) of the Statute of the ESCB ${ }^{40}$}

The increase in the representation of particular (State) interests is supposed to be eliminated or at least reduced by means of the amendments to the Statute of the ESCB and the ECB. Since the amendments were passed before the new Member States entered the EU, they were prevented from participating in the discussion. Changes were prepared almost in complete secrecy and without wide public debate. ${ }^{41}$ This accommodation of voting rules was explained in the preamble to the Decision of the Council 2003/223/EC as necessary for efficient and timely decision-making in an enlarged euro area. It is said that the rotation system represents an appropriate balance between continuity with the existing set-up, including a balanced assignment of voting rights between the six members of the Executive Board and the other members of the

\footnotetext{
37 Protocol (n 33).

38 Protocol (n 33).

39 HK Scheller, The European Central Bank: History, Role and Functions (ECB 2004) 54.

40 The Statute was changed with the Decision of the Council, Meeting in the Composition of the Heads of State or Government of 21 March 2003, on an amendment to Article 10.2 of the Statute of the European System of Central Banks and of the European Central Bank $(2003 / 223 / \mathrm{EC})$.

${ }^{41}$ Ansgar Belke, 'The Rotation Model Is Not Sustainable' (2003) 38(3) Intereconomics: Review of European Economic Policy 119.
} 
Governing Council and the need to ensure efficient decision-making in a substantially enlarged Governing Council. Besides, the rotation system should avoid creating situations in which governors with a voting right are from national central banks (NCBs) of Member States which, taken together, are perceived as unrepresentative of the euro area economy as a whole. The gross domestic product (GDP) and monetary financial institution (MFI) weightings are said to be appropriate because the impact of central bank decisions is greater in members with larger economies than in those with smaller economies and because the counterparties of central bank operations belong to the MFI sector. The establishment of a rotation system is scheduled to take place in two stages. As the number of governors exceeds fifteen, they will be allocated to two groups, and finally when the number of governors exceeds twenty-one, they will be allocated to three groups.

Slovenia was the first of the new Member States to enter the European Monetary Union in 2007. Malta and Cyprus followed in 2008, Slovakia joined in 2009 and Estonia in 2011. Although it seemed that a further broad enlargement of the Monetary Union would follow the enlargement of the European Union quite soon, the situation appears to be rather different at the moment. Several EU Member States decided to withdraw their already planned target date for the adoption of the euro. Lithuania and Estonia planned to introduce the euro in 2007, but they were not capable of fulfilling the Maastricht convergence criteria. Estonia postponed the target date to January 2008, but was forced to suspend it for an indefinite period. Eventually, it managed to introduce the euro in 2011. The Czech Republic and Hungary also postponed their target dates, while Sweden, Poland and Bulgaria never determined one. Currently, the only country with a target date for the introduction of the euro is Romania that plans to introduce the common currency in 2014. ${ }^{42}$ Except for Sweden which stalled preparations for the adoption of the euro due to the negative outcome of the referendum held in 2003, all other countries postponed the target date because of the unfavourable economic situation. Current economic conditions do not look very encouraging for the early fulfilment of the convergence criteria, especially the inflation criterion. Current economic conditions do not look very encouraging for the early fulfilment of the convergence criteria, especially the criteria concerning public debt and budget deficit, so a further enlargement can hardly be expected any time soon.

At first, the aforementioned changes of the Statute of the ESCB were supposed to come into effect in 2009 when the euro zone had six-

42 Commission, Fifth report on the practical preparations for the future enlargement of the euro area (Communication) COM (2007) 434 final. 
teen members. However, the Governing Council had the possibility to postpone the start of the rotation system, which was done in December $2008 .{ }^{43}$ Thus, the rotation system is expected to start when three additional countries enter the euro zone which will then have nineteen members.

As already mentioned, allocation to groups will be done according to a ranking of the size of the share of the Member State central bank in the aggregate GDP at market prices and in the total aggregated balance sheet of the MFIs of the Member States which have adopted the euro. Gross domestic product at market prices is the final result of the production activity of resident producer units. ${ }^{44}$ Monetary financial institutions are resident credit institutions as defined by Community law, and other resident financial institutions whose business is to receive deposits and/or close substitutes for deposits from entities other than MFIs and to grant credit for their own account (at least in economic terms) and/or make investments in securities. In practice, they include the European Central Bank, the national central banks of the euro area countries, and credit institutions and money market funds located in the euro area.

The shares in the aggregate gross domestic product at market prices and in the total aggregated balance sheet of monetary financial institutions will be assigned weighting of $5 / 6$ and $1 / 6$, respectively. The choice of the financial development criterion (MFI assets) has been heavily criticised, since it grants privilege to countries with better-developed banking systems, especially to Luxembourg. Besides that, no justification has been given for the choice of $1 /{ }_{6}$ weighting. ${ }^{45}$ The first group based on ranking depending on the previously described criteria will be composed of five governors and the second group will be made up of the remaining governors. The first group will be assigned four voting rights and the

\footnotetext{
43 Decision of the ECB of 18 December 2008 to postpone the start of the rotation system in the Governing Council of the ECB, ECB/2008/29.

44 It can be defined in three ways: as a sum of gross value added of the various institutional sectors or the various industries plus taxes and less subsidies on products (which are not allocated to sectors and industries). It is also the balancing item in the total economy production account; as the sum of final uses of goods and services by resident institutional units (actual final consumption and gross capital formation), plus exports and minus imports of goods and services and as the sum of uses in the total economy generation of income account (compensation of employees, taxes on production and imports less subsidies, gross operating surplus and mixed income of the total economy). ESA 1995

<http://forum.europa.eu.int/irc/dsis/nfaccount/info/data/esa95/en/een00383.htm> accessed 2 July 2011.

45 Daniel Gros, 'An Opportunity Missed!' (2003) 38(3) Intereconomics: Review of European Economic Policy 126; Michael R Frenkel and Ralf M Fendel, 'The New ECB Voting System: Some Room for Improvement' (2003) 38 Intereconomics: Review of European Economic Policy 337; EE Meade, 'A (Critical) Appraisal of the ECB's Voting Reform' (2003) 38(3) Intereconomics: Review of European Economic Policy 131.
} 
second group eleven. Precise voting rights were defined in ECB/2009/5 which states that the voting rights within each group shall rotate every month, starting on the first day of the first month of the implementation of the rotation system. For the first group, the number of voting rights that rotate in each one-month period will be one; while for the second and third groups, the number of voting rights that rotate in each onemonth period will be equal to the difference between the number of governors allocated to the group and the number of voting rights assigned to it, minus two.

Table 1: Allocation of membership and votes in groups under the rotation system.

\begin{tabular}{|l|c|c|c|c|c|c|c|c|c|c|c|c|}
\hline \multirow{2}{*}{$\begin{array}{l}\text { Members of } \\
\text { groups and their } \\
\text { voting rights }\end{array}$} & \multicolumn{10}{|c|}{ Euro area members } \\
\cline { 2 - 18 } & 16 & 17 & 18 & 19 & 20 & 21 & 22 & 23 & 24 & 25 & 26 & 27 \\
\hline $1^{\text {st }}$ group members & 5 & 5 & 5 & 5 & 5 & 5 & 5 & 5 & 5 & 5 & 5 & 5 \\
\hline Number of votes & 4 & 4 & 4 & 4 & 4 & 4 & 4 & 4 & 4 & 4 & 4 & 4 \\
\hline $2^{\text {nd }}$ group members & 11 & 12 & 13 & 14 & 15 & 16 & 11 & 12 & 12 & 13 & 13 & 14 \\
\hline Number of votes & 11 & 11 & 11 & 11 & 11 & 11 & 8 & 8 & 8 & 8 & 8 & 8 \\
\hline $3^{\text {rd }}$ group members & $/$ & $/$ & $/$ & $/$ & $/$ & $/$ & 6 & 6 & 7 & 7 & 8 & 8 \\
\hline Number of votes & $/$ & $/$ & $/$ & $/$ & $/$ & $/$ & 3 & 3 & 3 & 3 & 3 & 3 \\
\hline
\end{tabular}

Source: Ahtik ${ }^{46}$

Calculations based on the assumption of twenty-five countries participating in the euro area show that members of the first group will be suspended from voting in $20 \%$ of the time periods, members of the second group once 'completed' in $43 \%$ of the time periods, whereas members of the third group will be suspended from voting in $57.1 \%$ of the time periods. ${ }^{47}$

The legal framework described in the previous section does not provide precise information about which country will be in which group. The available data allow us to make a rough simulation of the voting rights,

\footnotetext{
46 Meta Ahtik, 'Central Banking in Slovenia from Yugoslavia to Membership in the Euro Area' (2008) in Európske združenie študentov práva (ELSA) Úloha práva v procese menovej sukcie : zbornik z medzinárodnej EUROkonferencie (ELSA 2008).

47 The situation will be even worse for third group members, when its membership increases; in fact, once the number of governors reaches 27 , they will perform their voting right only in $37.5 \%$ of cases. See Belke (n 41) 121 .
} 
which is done based on the most recent and most appropriate data currently available. For GDP at market prices, the data for 2007 have been used $^{48}$ and for the data on MFI aggregated balances the average of the eleven or (if available) twelve months of 2007 have been collected. The data do not include the balances of the Eurosystem (for the members of the euro zone) or national central banks (for the non-members of the euro zone) although article 10.2 of the Statute of the ESCB prescribes that the total aggregated balance sheet of the monetary financial institutions should be used. The statistical framework applying in the European Community at the time of the calculation that is not yet known should be used. Since the argument for using the criterion of MFI assets was that the importance of central bank counterparties should be taken into account, this method could be most appropriate. Besides, assets of the central banks represent only about $0.1 \%$ of the total assets of the MFI. ${ }^{49}$ Several unknowns have to be considered, but it is possible to gain an insight of the structure of the groups.

Table 2: Membership of the groups when nineteen countries enter the euro zone: only countries that are already included in the ERM II, without Denmark that has an opt-out clause.

\begin{tabular}{|l|l|r|l|}
\hline & $\mathbf{1}^{\text {st }}$ group & & $\mathbf{2}^{\text {nd }}$ group \\
\hline 1. & Germany & 6. & Belgium \\
\hline 2. & France & 7. & Austria \\
\hline 3. & Italy & 8. & Ireland \\
\hline 4. & Spain & 9. & Greece \\
\hline 5. & Netherlands & 10. & Finland \\
\hline & & 11. & Portugal \\
\hline & & 12. & Luxembourg \\
\hline & & 13. & Slovakia \\
\hline & & 14. & Slovenia \\
\hline & & 15. & Lithuania \\
\hline & & 16. & Latvia \\
\hline & & 17. & Cyprus \\
\hline & & 18. & Estonia \\
\hline & & 19. & Malta \\
\hline
\end{tabular}

Source: Ahtik ${ }^{50}$

48 Eurostat estimations are used if actual data are not available.

49 Frenkel and Fendel (n 45) 337.

50 Ahtik (n 46). 
Table 2 shows the simulation of membership of the groups in a monetary union of nineteen countries. If this situation is compared to the situation based on the data from $2002,{ }^{51}$ an improvement in the ratings of Ireland and Greece and a worsening of the ratings of Portugal can be observed. The composition of groups has not changed.

It can be noticed that the members of the first group are also the four largest states in terms of population, which was most commonly proposed as a more appropriate criterion than the MFI total assets criterion. ${ }^{52}$ The only small(er) country in the first group is the Netherlands. Economic development is obviously the criterion that has prevailed. Austria, Ireland and especially Luxembourg have improved their positions, but not their group status, because the MFI total assets criterion has been used.

Table 3: Membership of the groups if all of the current members of the European Union except Denmark and the UK (that have opt-out clauses) entered the euro-zone.

\begin{tabular}{|l|l|l|l|l|l|}
\hline & $\mathbf{1}^{\text {st }}$ group & & $\mathbf{2}^{\text {nd }}$ group & & $\mathbf{3}^{\text {rd }}$ group \\
\hline 1. & Germany & 6. & Belgium & 19. & Slovenia \\
\hline 2. & France & 7. & Sweden & 20. & Bulgaria \\
\hline 3. & Italy & 8. & Austria & 21. & Lithuania \\
\hline 4. & Spain & 9. & Poland & 22. & Latvia \\
\hline 5. & Netherlands & 10. & Ireland & 23. & Cyprus \\
\hline & & 11. & Greece & 24. & Estonia \\
\hline & & 12. & Finland & 25. & Malta \\
\hline & & 13. & Portugal & & \\
\hline & & 14. & Czech Republic & & \\
\hline & & 15. & Romania & & \\
\hline & & 16. & Luxembourg & & \\
\hline & & 17. & Hungary & & \\
\hline & & 18. & Slovakia & & \\
\hline
\end{tabular}

The above conclusion can be confirmed by looking at Table 3, which shows the situation in which all of the current European Union members (with the exception of Denmark and the United Kingdom) will have also entered the monetary union. Members of the third group are only new Member States.

51 Gros (n 45) 125.

52 Frenkel and Fendel (n 45) 337. 
It is true that decision-making is difficult and more complicated in large bodies, but members of the Governing Council would be allowed to take part in the meetings, even if they did not possess a voting right at the moment of decision-making. The discussion would take exactly the same time as if all the Governing Council members had a voting right or even longer, because members without a voting right would try to influence other members' opinions. ${ }^{53}$ Decision-making would not be made any easier, because the pure act of voting itself does not take much time.

It is quite clear ${ }^{54}$ that the only reason for passing the changes of the Statute of the ESCB and the ECB is the fear that small countries, new Member States that are entering the euro area, could prevail in the Governing Council. Is this fear justified? As already explained, new members are not likely to have a majority in the Governing Council soon, because they will not be able to enter the euro zone quickly. In addition, there are only twelve 'new' members in the European Union, and only ten of them are Central and Eastern European countries, compared to twelve old euro area members. Therefore, this kind of fear is not justified. On the other hand, the new regulation would enable a coalition of smaller countries representing just $10 \%$ of the euro-zone economy to prevail. ${ }^{55}$ Besides, smaller members are characterised by intensive trade and financial ties with larger members of the euro area, so that they share their economic fate.

The ECB was considered one of the institutions of the Union whose officials, like Commission officials, were not supposed to follow national interests but to act in the best interest of the Union as a whole, although, unlike commissioners, national central bank governors are employed by their national central banks. However, the rotation system for the Commission, introduced by the Treaty of Lisbon, is based on the criterion of equality between Member States. ${ }^{56}$

Decision-making, as it is now regulated in article 10.2 of the Statute of the ESCB and the ECB, would not contribute to the creation of the 'European spirit', but would mean increased division between euro

\footnotetext{
53 Ingo Friedrich 'Reform of the Decision-making Rules of the ECB Council in View of EMU Enlargement' (2003) 38(3) Intereconomics: Review of European Economic Policy 118.

54 This conclusion is confirmed by the timing of the decision of the Council.

55 Friedrich (n 53).

56 'In accordance with Article 9 D(5) of the Treaty on European Union, the members of the Commission shall be chosen on the basis of a system of rotation established unanimously by the European Council and on the basis of the following principles: (a) Member States shall be treated on a strictly equal footing as regards determination of the sequence of, and the time spent by, their nationals as members of the Commission; consequently, the difference between the total number of terms of office held by nationals of any given pair of Member States may never be more than one; (b) subject to point (a), each successive Commission shall be so composed as to reflect satisfactorily the demographic and geographical range of all the Member States. Treaty of Lisbon, art 211 a.
} 
area members. The public may find the decision-making process less transparent and less comprehensible. ${ }^{57}$ Governors may start to think in national categories. Absence from decision-making would violate the accountability principle, reduce the responsibility of members for monetary decisions and heighten non-transparency. ${ }^{58}$

Another problem that could emerge is inconsistency of decision-making within the Governing Council. In fact, a group of countries may wait for a desired composition of the Council in order for a decision favourable to them to be reached. Of course, this decision could be changed in the next composition of the Governing Council.

\section{Conclusion}

Slovenia and Croatia have gone through several monetary changes in the last decades and legal continuity has been a crucial element in all of these changes. The two countries were parts of the former socialist Yugoslavia, characterised by centrally planned decision-making that also determined central banking. Although Slovenia and Croatia have not travelled a long way on their own, their experiences with an independent central bank cannot be neglected. After gaining their independence, they introduced their own currencies and established modern independent central banks. The legal structure defined in Slovenia in 1991 was preserved in 2002 , although several changes were implemented with the aim of further modernising the Bank of Slovenia, when a new act was passed preparing the Slovenian Central Bank for the adoption of the euro in 2007. The Bank of Slovenia became part of the Eurosystem and its governor is a member of the Governing Council of the ECB that decides on the monetary policy of the euro area. The one person, one vote principle is used, although it is supposed to be replaced by a rather complicated rotation system that will bring inequality among Member States. The Croatian National Bank went through several changes from 1991 to 2008 which aimed at strengthening its independence but was also targeted at the eventual membership of Croatia in the euro zone. Experience shows that decision-making deficiencies are usually revealed in times of crisis, ${ }^{59}$ but the European Union could prepare for such an event in advance by introducing a more efficient and at the same time a more equitable system.

\footnotetext{
57 See Belke (n 41) 122.

58 ibid 120.

59 Philippe Moutot, Alexander Jung and Francesco Paolo Mongelli, The Workings of the Eurosystem, Monetary Policy Preparations and Decision-making: Selected Issues (2008) ECB Occasional Paper Series, No 79, 10. The authors claim that break-downs of monetary unions are usually a consequence of political factors rather than economic or financial crises. However, this is not necessarily true, because political crises often emerge when times of economic prosperity end.
} 